DOI: 10.17707/AgricultForest.65.2.07

\author{
Andjelka ŠĆEPANOVIĆ*, Slavica VUJOVIĆ, \\ Milica IVANOVIĆ, Staša ŠĆEPANOVIĆ ${ }^{1}$
}

\title{
BODY GROWTH, DEVELOPMENT AND NUTRITIONAL STATUES OF PUBERTY CHILDREN IN URBAN AND RURAL AREAS OF PODGORICA AND BERANE IN MONTENEGRO
}

\begin{abstract}
SUMMARY
The puberty represents one of the most critical children and adolescents growth and development period, when considerable differences between age and sex may be observed. The aim of this paper was to determine body height, body mass, menarche and nutritional status in children aged 13 and 14 in Podgorica (urban area) and Berane (the rural area around Berane). This overview study, according to International Biology Program (IBP) instructions, was performed in 2018 in elementary schools in Podgorica and Berane, and includes children aged 13 and 14. In Podgorica, 216 students underwent analysis, while 214 of them underwent analysis in Berane. Boys from Podgorica had a slightly higher average body height, body weight and body mass index (BMI) in examined years compared to boys from Berane, but there was no statistical significance. Girls aged 14 years from Podgorica are slightly higher average body height and BMI and statistically significant $(p<0.05)$ higher mean body weight compared to girls from Berane. An analysis of the nutritional status of children aged 13 and 14 in Podgorica and Berane shows that the highest percentage of boys $(68.5 \%$ from Podgorica and 68.4\% from Berane) and girls (75.7\% from Podgorica and 74\% from Berane) are in the category of normal weight. Girls in Podgorica have a menarche with $12.15 \pm 0.84$ and girls in Berane with $12.51 \pm 0.68$ years, which is a statistically significant difference $(p=0.03)$. The girls in Podgorica have been puberty earlier than their peers in Berane. Higher obesity rate in girls in urban areas, leads to a conclusion that the attention should be particularly directed towards the diet and origin of food, especially in child development period.
\end{abstract}

Keywords: body height, body weight, BMI, nutritive status, menarche.

\section{INTRODUCTION}

Growth and development represent the basic parameters of children age, that develop according to genetically determined rules and under the influence of the environment. The processes are mutually conditioned, and defined by the

\footnotetext{
${ }^{1}$ Andjelka Scepanovic* (Corresponding author: andjelka.s@ucg.ac.me), Slavica Vujovic, University of Montenegro, Faculty of Natural Science and Mathematics, Department of Biology, Dzordza Vasingtona bb, Podgorica, MONTENEGRO; Milica Ivanovic, Primary School "Lubnice", Berane, MONTENEGRO; Staša Šćepanović, University of Belgrade, Faculty of Medicine, SERBIA.

Notes: The authors declare that they have no conflicts of interest. Authorship Form signed online.
} 
changes in body height, weight, proportions and body form, as well as physiological functions. The most critical period during these processes is definitely the puberty, when most significant changes in growth and development occur, as well as the most significant differences in sexual maturity. The puberty is connected to the increased growth, fat weight and obesity. The most reliable indicator of the puberty in girls is the menarche. Monitoring growth and development of children and adolescents is based on the evaluation of morphological parameters that enable the comparison of populations living in different external conditions, as well as different periods. Since parameters are changeable both in terms of time and space, it is significant to ensure their constant evaluation. Body height is one of the significant indicators of growth and nutritional status at children. Another, but not less important anthropometrical parameter is body weight, especially its relation to the age. Deviations in this relation indicate disorder in nutritional condition. Body weight is a basic parameter of the level and pace of bodily development, however it is considered a so - called dynamic - changeable dimension, being subject to influence of the environment and may demonstrate huge variations, even within a day (Vujmilović, 2012). Even though the body weight is closely connected to physical and motor development, significantly more stable indicator of growth and development is body height (Podstawski and Borysawski, 2012). It is evident that the development of standard as well as irregular nutrition cause greater occurrence of obesity - modern day epidemic. Obese children and adolescents have greater chances of being obese as adults (Wang and Lobstein, 2006). Often the literature connects increased body weight with reduced motor skills connected to physical activities (Delaš et al. 2008). Children who are obese or have increased body weight are more prone to reduced physical activity, or this reduced physical activity is the cause of increased body weight (Planišec and Matejek, 2004). Therefore, anthropometric parameters are also significant in evaluating motor abilities with children (Ceylan et al. 2014).

In 2014, World Health Organization (WHO) adopted a Global Strategy on Diet, Physical Activity and Health, with its primary aim of enhancing the health with proper diet and physical activity. Having in mind a modern lifestyle, with inadequate nutrition and little physical activity, along with genetics, a lot attention has been recently paid to the increase of BMI, hence this body index has been included in all the research related to evaluation of children and adolescents' development. Nowadays, obesity is considered to occur as a consequence of several factors - genetic traits, phycological, sociological (Tatar, 2014).

Different locations were not chosen randomly, but with an intention to determine potential differences in the level of physical development based on morphological characteristics of the examinees, having regard to differences in geographical, climate - wise, nutritional, socio - economic terms, and many more. There are numerous studies concerned with ecological and other characteristics of specific regions of Montenegro. Numerous researchers have 
done studies on organic food production, autochthonous species and other characteristics of rural, northern region of Montenegro (Mirecki, 2011; Tesovic et al. 2012; Bozovic and Jacimovic, 2012; Sebek, 2013). All of these studies, might help understand potential developmental and morphological differences of the children in urban compared to rural areas.

The aim of this paper was to determine body height, body mass, menarche and nutritional status in children aged 13 and 14 in urban and rural areas in Montenegro.

\section{MATERIAL AND METHODS}

A sample of this cross - sectional study consist of students aged 13 and 14, with 216 (105 boys and 111 girls) examined in Podgorica, and 214 students (114 boys and 100 girls) examined in Berane. The survey was conducted in September 2016 by means of a random test sample, covering elementary schools students in Podgorica, and elementary schools students from the rural area around Berane.

Podgorica is an administrative center, the capital and the biggest town located in southern part of the Republic, with $44,5 \mathrm{~m}$ altitude. It has Mediterranean climate with a considerable influence of the adjacent sea, with extremely hot summers where temperatures during July and August exceed 40 degrees Celsius. Most recent census recorded around 250000 population. On the other hand, Berane is a town located on the north - east of Montenegro, with 703 m altitude, having moderate continental climate with strong impact of mountain climate. Average annual temperature of Berane is $9,4 C^{\circ} .2003$ Census recorded population of 11 776. Municipality of Berane accounts for one of the poorest municipalities in Montenegro. Different locations were not chosen randomly, but with an intention to determine potential differences in the level of physical development based on morphological characteristics of the examinees, having regard to differences in geographical, climate - wise, socio - economic terms, and many more.

Decimal ages on the date of the survey and date of birth have been calculated for each examinee. Data for the menarche have been taken via status quo method, while the age of the occurrence of menarche with girls has been calculated from the date of birth and the date of the occurrence of menarche. Standard anthropological instruments have been used to calculate body height and body weight. Body height has been calculated by means of an anthropometer with the precision of $0.1 \mathrm{~cm}$. Body weight has been calculated by means of a digital scale with the precision of $0.1 \mathrm{~kg}$. In order to evaluate the nutritional status, BMI has been calculated as a ratio between body weight in kilograms and body height in square meters for age and sex. Percentile values for BMI have also been calculated, based on which the evaluation of the nutritional condition in children was performed, as recommended by NHANES I (Must et al. 1991), according to which: BMI $<\mathrm{P} 5$ are under malnourished: from P5 to P15 are 
moderately malnourished; from P15 to P85 normally nourished; P85 to P95 moderately obese (overweight), while obese are those with $>$ P95.

Difference between average values (body height, body weight and BMI) of the students from surveyed locations, as well as sexual differences have been tested by independent t-test.

This survey has been conducted in line with Helsinki Declaration with the consent of all parents, school principals and the Dean of the Faculty of Science and Mathematics. This survey was approved in advance by the College of Natural Sciences and Mathematics and all the directors of elementary schools in Podgorica and Berane. Each participant voluntarily provided written informed consent before participating.

\section{RESULTS}

Average values of height, weight and BMI of boys from Podgorica and Berane and total sample by age are shown in Table 1.

Table 1. Average values of height, weight and BMI of boys from Podgorica and Berane

\begin{tabular}{|c|c|c|c|c|c|c|c|c|c|c|c|}
\hline & \multirow{2}{*}{$\begin{array}{c}\text { Age } \\
\text { (years) }\end{array}$} & \multicolumn{3}{|c|}{ Podgorica } & \multicolumn{3}{|c|}{ Berane } & \multicolumn{3}{|c|}{ Total } & \multirow[b]{2}{*}{ p value $e^{\ddagger}$} \\
\hline & & $\mathrm{N}$ & Mean & SD & $\mathrm{N}$ & Mean & SD & $\mathrm{N}$ & Mean & SD & \\
\hline \multirow{2}{*}{$\begin{array}{l}\text { Height } \\
\text { (cm) }\end{array}$} & 13 & 52 & 170.86 & 8.02 & 55 & 168.49 & 8.90 & 107 & 169.68 & 8.46 & 0.32 \\
\hline & 14 & 53 & 173.36 & 8.09 & 59 & 171.17 & 9.53 & 112 & 172.27 & 8.81 & 0.39 \\
\hline \multirow{2}{*}{$\begin{array}{l}\text { Weight } \\
\text { (kg) }\end{array}$} & 13 & 52 & 62.32 & 11.71 & 55 & 57.51 & 10.5 & 107 & 59.92 & 11.11 & 0.12 \\
\hline & 14 & 53 & 63.59 & 11.66 & 59 & 60.52 & 13.0 & 112 & 62.06 & 12.35 & 0.39 \\
\hline \multirow{2}{*}{$\begin{array}{l}\text { BMI } \\
\left(\mathrm{kg} / \mathrm{m}^{2}\right)\end{array}$} & 13 & 52 & 21.26 & 3.2 & 55 & 20.19 & 3.13 & 107 & 20.73 & 3.21 & 0.23 \\
\hline & 14 & 53 & 21.14 & 3.50 & 59 & 20.52 & 3.41 & 112 & 20.83 & 3.4 & 0.53 \\
\hline
\end{tabular}

${ }^{\ddagger}$ t-test independent ; N-number; SD-standard deviation; BMI-body mass index

The height of the boy's increased with an average of $169.68 \pm 8.46$ to $172.27 \pm 8.81 \mathrm{~cm}$ and was higher in both boys in Podgorica. Body weight also increased with age and amounted to $59.92 \pm 11.11 \mathrm{~kg}$ in 13 years and $62.06 \pm$ $12.35 \mathrm{~kg}$ in 14 years. Boys from Podgorica are larger body masses in both examined years than boys from Berane. Average BMI values are similar in both examined years $(20.73 \pm 3.21 \mathrm{~kg} / \mathrm{m} 2$ in 13 years and $20.83 \pm 3.46 \mathrm{~kg} / \mathrm{m} 2$ in 14 years) and are higher in boyfriends from Podgorica (Table 1).

Average values of height, weight and BMI of girls from Podgorica and Berane and total sample by age are shown in Table 2.

In girls in the overall sample, the height of the body is approximately the same in the examined ages $(165.16 \pm 6.31 \mathrm{~cm}$ in 13 years and $165.62 \pm 6.86 \mathrm{~cm}$ in 14 years), while the average body weight values $(58.55 \pm 9.68 \mathrm{~kg}$ in 13 years and $55.01 \pm 8.46 \mathrm{~kg}$ in 14 years $)$ and BMI (21.45 $\pm 3.27 \mathrm{~kg} / \mathrm{m} 2$ in 13 years and $20.03 \pm 2.63 \mathrm{~kg} / \mathrm{m} 2$ in 14 years) decreased. Girls aged 13 years from Berane had higher average body height, body weight and BMI. 
Table 2. Average values of height, weight and BMI of girls from Podgorica and Berane

\begin{tabular}{|c|c|c|c|c|c|c|c|c|c|c|c|}
\hline & \multirow{2}{*}{$\begin{array}{l}\text { Age } \\
\text { (years) }\end{array}$} & \multicolumn{3}{|c|}{ Podgorica } & \multicolumn{3}{|c|}{ Berane } & \multicolumn{3}{|c|}{ Total } & \multirow[b]{2}{*}{ p value } \\
\hline & & $\mathrm{N}$ & Mean & $\mathrm{SD}$ & $\mathrm{N}$ & Mean & SD & $\mathrm{N}$ & Mean & SD & \\
\hline \multirow{2}{*}{$\begin{array}{l}\text { Height } \\
\text { (cm) }\end{array}$} & 13 & 55 & 164.36 & 5.53 & 49 & 165.95 & 7.08 & 104 & 165.16 & 6.31 & 0.34 \\
\hline & 14 & 59 & 166.65 & 7.68 & 51 & 164.58 & 6.03 & 107 & 165.62 & 6.86 & 0.33 \\
\hline \multirow{2}{*}{$\begin{array}{l}\text { Weight } \\
(\mathrm{kg})\end{array}$} & 13 & 55 & 56.79 & 8.00 & 49 & 60.31 & 11.35 & 104 & 58.55 & 9.68 & 0.17 \\
\hline & 14 & 59 & 57.94 & 8.40 & 51 & 52.08 & 8.52 & 107 & 55.01 & 8.46 & $0.03 *$ \\
\hline \multirow{2}{*}{$\begin{array}{l}\text { BMI } \\
\left(\mathrm{kg} / \mathrm{m}^{2}\right)\end{array}$} & 13 & 55 & 20.98 & 2.67 & 49 & 21.91 & 3.87 & 104 & 21.45 & 3.27 & 0.28 \\
\hline & 14 & 59 & 20.82 & 2.49 & 51 & 19.24 & 2.77 & 107 & 20.03 & 2.63 & 0.06 \\
\hline
\end{tabular}

${ }^{\ddagger}$ t-test independent ; N-number; SD-standard deviation; BMI-body mass index; ${ }^{*} \mathrm{p}<0.05$

Girls aged 14 years from Podgorica are slightly higher average body height and BMI and statistically significant ( $<$ 0.05) higher mean body weight compared to girls from Berane (Table 2).

The results presented in Tables 1 . and Tables 2., which relate to gender differences, showed that boys from Podgorica in both examined years were of higher values of all tested parameters compared to girls, while girls from Berane age 13 had a higher body mass and BMI in relation to boys.

The results of the t-test of independence showed statistically significantly higher body height and body mass in 13-year-old boys from Podgorica ( $p<0.05)$ and 14-year-old boys from Berane $(p<0.01)$ compared to girls. There were no significant gender differences in BMI.

Table 3. presents the nutritive status of boys and girls from Podgorica and Berane.

Table 3. Nutritive status of boys and girls from Podgorica and Berane \% (N)

\begin{tabular}{lcccc}
\hline & \multicolumn{2}{c}{ Podgorica } & \multicolumn{2}{c}{ Berane } \\
& Boys (105) & Girls (111) & Boys (114) & Girls (100) \\
\hline Underweight & $4.8 \%(5)$ & $3.6 \%(4)$ & $7 \%(8)$ & $8 \%(8)$ \\
Moderate underweight & $12.4 \%(13)$ & $6.3 \%(7)$ & $14.9 \%(17)$ & $9 \%(9)$ \\
Normal & $68.5 \%(72)$ & $75.7 \%(84)$ & $68.4 \%(78)$ & $74 \%(74)$ \\
Overweight & $9.5 \%(10)$ & $10.8 \%(12)$ & $5.3 \%(6)$ & $6 \%(6)$ \\
Obesity & $4.8 \%(5)$ & $3.6 \%(4)$ & $4.3 \%(5)$ & $5 \%(5)$ \\
\hline
\end{tabular}

An analysis of the nutritional status of children aged 13 and 14 in Podgorica and Berane shows that the highest percentage of boys $(68.5 \%$ from Podgorica and 68.4\% from Berane) and girls (75.7\% from Podgorica and 74\% from Berane) are in the category of normal weight. A higher percentage of boys (9.5\%) and girls (10.8\%) in Podgorica had an overweight compared to boys (5.3\%) and girls (6\%) in Berane. A slightly higher percentage of obese boys 
(4.8\% compared to 4.3\%) was observed in Podgorica, and girls (5\% compared to $3.6 \%$ ) in Berane. Fewer and moderately malnourished boys and girls were more in Berane than in Podgorica (Table 3).

Present menarche mean of girls from Podgorica and Berane were $12.15 \pm$ 0.84 and $12.51 \pm 0.68$ years, respectively, $\mathrm{p}=0.03$, so it this parameter was significantly higher in group from Berane. Menarche medians for female subjects aged 13 and 14 in Podgorica and Berane were $12.00 \pm 0.12$ and $13.00 \pm 0.10$ years respectively (Table 4).

Table 4. Menarche of girls from Podgorica and Berane $(\mathrm{N}=180)$

\begin{tabular}{lccc}
\hline & $\begin{array}{c}\text { Podgorica } \\
(\mathrm{N}=93)\end{array}$ & $\begin{array}{c}\text { Berane } \\
(\mathrm{N}=87)\end{array}$ & p value $^{\ddagger}$ \\
\hline Mean \pm SD (years) & $12.15 \pm 0.84$ & $12.51 \pm 0.68$ & $0.03^{*}$ \\
Median (years) & 12.00 & 13.00 & \\
Standard error (years) & 0.12 & 0.10 & \\
${ }^{\mp}$ t-test independent, SD- standard deviation; ${ }^{*} \mathrm{p}<0.05$ & &
\end{tabular}

\section{DISCUSION}

Mean values of height, body weight and BMI in boys from Podgorica are higher if compared in same parameters with peers in Berane, however statistically significant differences have not been proven. At girls, only in the age of 14 in relation to body weight the values are slightly higher in Podgorica, with significance $(166.65 \pm 7.68 \mathrm{~cm}$ compared to $164.58 \pm 6.03 \mathrm{~cm}, \mathrm{p}=0.33)$. Similar ratio of parameters was achieved in the analysis related to comparison of puberty population in Pljevlja and Podgorica (Scepanovic, 2001), for both sexes.

Results of the survey performed recently in Nikšić within fourteen - year old children compared to their peers in European countries, indicated that examinees in Montenegro have higher values in all three parameters when compared to Belgium, Spain, Slovakia, Lithuania, Estonia and Albania (Radulovic and Krivokapic, 2013). Mean values of the examined parameters with boys in Podgorica and Berane are higher than the same ones in Nikšić, which is not the case with girls from Berane. Results achieved indicate the need for further research of the children living in different regions, and for the research of the impact the environment, along with all its characteristics, has on children growth and development.

The analysis of the results achieved through anthropometrical measurements indicates that boys from Podgorica and Berane, in terms of weight and body height, as well as BMI, go ahead of the girls in both regions, which is expected for this age. Based on different research (Ivanović, 1996; Rakic, 2009; Bozic-Krstic et al. 2004), it has been known that boys of 13 and 14 years exceed girls in terms of height, as well as other parameters, which has been confirmed in these surveys as well.

Additionally, based on BMI values and the level of nutrition it can be concluded that majority of children are normally nourished. Overweight has been 
detected in $9.5 \%$ boys and $10.8 \%$ girls in Podgorica, slightly higher than the case with Berane (5.3\% boys and $6 \%$ girls). On the other hand, there are more malnourished boys and girls in Berane. Comparing the total obesity of surveyed population (14.30\% boys and $14.40 \%$ girls in Podgorica, and $9.6 \%$ boys and $11 \%$ girls in Berane) with the surveys in the neighborhood (Mirilov and Mirosavljev, 2004) it may be stated that children in Berane feature less percentage of total obesity, while Podgorica population almost fits the recent research in Novi Sad, where the frequency of complete obesity according to BMI is $14.20 \%$ in boys and $12.60 \%$ in girls. If the fact that in recent years the tendency for increased obesity and overweight in Europe for ages 13 to 17 reached 15\% both in boys and girls (Lobstein, et al. 2004), it is clear that such a trend is being present in our population, with a somewhat more favorable situation in Berane. The results definitely indicate an increased level of obese children in developed and bigger cities, which may be connected to earlier puberty. Results of numerous research also showed that the time of menarche is considerably connected to obesity (Salces et al. 2001; Laska-Mierzejewska, 1996; Rao et al. 1998, Scepanovic, 2013; Rakic, 2009).

Fat mass is being increased especially in girls, since body fat represents a significant energy deposit, which is need for normal function of female gonads (Phillips et al. 2003).

Also, postmenarchal girls are characterized by an increased fat weight (Rakic et al. 2013). That can explain the results obtained in this paper, where girls who are more obese from Podgorica get their menarche prior to the girls from Berane. The results show that Podgorica girls get their menarche at the age of $12.15 \pm 0.84$, with medians $12.00 \pm 0.12$ and in Berane $12.51 \pm 0.68$, with medians $13.00 \pm 0.10$, which has proven as statistically considerable difference. Monitoring of sexual development of primary - school girls in the region showed that the menarche in Vršac and other bigger towns in Vojvodina is obtained with 12.51 age on average, and medians is 12.50 age (Rakic, 2009), which is approximate to the values obtained within this paper. On the other hand, girls from Niš are characterized by later maturity, because the data say medians is 13.66 age (Cvetković et al. 2012).

However, recent studies in different European countries show different results. Therefore, girls from Podgorica mature earlier than girls from Turkey (Ekerbicer et al. 2007) and the Netherlands (Mul et al. 2001), and insignificantly later than girls from Greece (Papafimitriou et al. 2008) and Portugal (Padez and Rocha, 2003).

It is believed that better life conditions cause a better starting point for sexual development of girls. Parameters taken in consideration are nutrition, genes, but mother's education as well. Numerous studies deal with the issue of puberty onset in relation to life and environment conditions (Cole, 2000; 2003, Cukic; Hurbo 2008; Pavlica et al. 2012), which supports the statement that there are many different factors that condition growth and development of puberty population in different manners. 


\section{CONCLUSIONS}

Compared populations of children aged 13 and 14 in urban and rural areas do not statistically differ in terms of body height, body weight and BMI, except in girls from Podgorica aged 14 in terms of body weight when compared to their peers in Berane. Additionally, girls in Podgorica mature in sexual terms earlier.

Results obtain indicate the need for further research of the children living in different regions, in order to achieve better insight into the changes of morphological parameters, especially indicators of sexual development.

Higher obesity rate in girls in urban areas, leads to a conclusion that the attention should be particularly directed towards the diet and origin of food, especially in child development period.

\section{REFERENCES}

Bozic-Krstic, V., Pavlica T., Rakic, R., (2004). Body height and weight of children in Novi Sad. Ann of Hum Biol., 31(3), pp.356-363.

Bozovic, Dj., Jacimovic, J. (2012). Phenological propertics of plums under the conditions of Northern Montenegro. Agriculture and Forestry, 58 (4), pp. 153-159.

Ceylan, H. I., Saygin, O., Irez, G. B. (2014). The Examining body composition, sprint and coordination characteristics of the children aged $7-12$ years. Anthropologist, 18(3), pp. 859-67.

Cole, T. J. (2000). Secular trends in growth. Proc. Nutr. Soc., 59(2), pp. 317-24.

Cole, T. J. (2003). The secular trend in human physical growth: a biological view. Econ. Hum. Biol., 1(2), pp.161-8.

Cukic, M., Vasic, B., Jelenkovic, B., Cukic, M. (2012). Nutritional status of children before starting school in two generations of children born in 1994 and 2004. Timoc. Med. Glas., 37(3), pp. 134-8.

Cvetković, M., Najman, S., Nikolić, M., Živanov-Čurlis, J. (2012). Antropološke karakteristike premenarhalnih i postmenarhalnih devojčica Niša iz različitih vremenskih perioda. Glasnik ADS., 47, pp. 269-275.

Delaš, N., Tudor, A., Ružić, L., Šestan, B. (2008). Povezanost stupnja uhranjenosti djece 5-8 razreda osnovne škole i nekih motoričkih sposobnosti. Hrvatski sportskomedicinski vjesnik Sv. 23, pp. 35-45.

Ekerbicer, HC., Celik, M., Kiran, H., Kiran, G. (2007). Age at menarche in Turkish adolescents in Kahramanmaras, Easten Mediterranean region of Turkey. Eur J Contracept Reprod Helth Care. 12(3), pp. 289-93.

Hurbo, T. (2008). Secular changes in height, weight and chest circumference of 4-7 year old children from Minsk in the 20th century. Acta Med. Litu.,15(4), pp. 222-8.

Ivanović, B. (1996): Antropologija. Podgorica

Laska-Mierzejewska, T., Luczak, E. (1996). Uwarunkowania wysokiej zaleznosci pomiedzy budowa ciala i wiekiem menarchy (The relationship between the body build and menarcheal age). Przeglad Antropologiczny, 59, pp. 115-119.

Lobstein, T., Baur, L., Uauy, R. IASO International Obesity Task Force. (2004). Obesity in children and youn people: a crisis in public health. Obes Rev., 5(1), pp. 4-104.

Mirecki, S. (2011). Protection of traditional dairy products in Montenegro. Agriculture and Forestry, 57(2), pp. 27-42.

Mirilov, J., Mirosavljev, M. (2004). Antropometrijski pokazatelji gojaznosti dece skolskog uzrasta. Hrana i ishrana., 45(1-2), pp. 7-9. 
Mul, D., Fredriks, AM., Van Buuren, S., Oostdijk, W., Verloove-Vanhorick, SP., Wit, JM. (2001). Pubertal development in The Netherlands 1965-1997. Pediatr Res., 50(4), pp.479-86.

Must, A., Dallal, G.E., Dietz, W.H. (1991): Reference for obesity: 85th and 95th percentiles of body mass index (wt/ht2) and triceps scinfold thickness. Am J Clin Nutr., 53 (4), pp. 939-846.

Padez, C., Rocha, MA. (2003). Age at menarche in Coimbra (Portugal) school girls: a note on the secular schanges. Ann Hum Biol., 30(5), pp.622-632.

Papadimitriou, A., Fytanidis, G., Douros, K., Bakula, C., Nicolaidou, P., Fretzayas, A. (2008). Age at menarche in contemporary Greek girls: evidence for levelling-off of the secular trend. Acta Pediatrica., 97(6), pp.812-815.

Pavlica, T., Rakic, R., Djuricanin, A., Korovljev, D. \& Srdic, B. (2012). Growth and nutritional status of children and adolescents from 7 to 19 years of age in the town of Jagodina (Central Serbia). HealthMED, 6(1), pp. 284-93.

Phillips, SM., Bandini, LG., Compton, DV., Naumova, EN., Must, A. (2003). A longitudinal comparison of body composition by total body water and bioelectrical impedance in adolescent girls. J Nutr., 133(5), pp.1419-25.

Planinšec, J., Matejek, Č. (2004). Differences in Physical Activity between Nonoverweight, Overweight and Obese Children. Collegium antropologicum, 28(2), pp. 747-754.

Podstawski, R., Borysawski, K. (2012). Relationships between selected anthropometric features and motor abilities of children aged 7 - 9. Clin.Kinesiol., 66(4), pp. 8290 .

Radulovic, B., Krivokapic, D. (2013). Physical Development And Physical Skills Of Fourteen Years Old Pupils In Montenegro Compared To The Peers From European Countries. SportMont, XI (37,38,39), pp. 218-224

Rakić, R. (2009). The Significance of some Environmental Factors on the Growth and Development of Children and Adolescents. PhD Thesis. University of Novi Sad Faculty of Science - Department of Biology and Ecology.

Rakic, R., Pavlica, T., Bozic-Krstic, V., Jovicic D., Novakovic, M., Drobac D. (2013). Morfološke karakteristike i telesna kompozicija kod premenarhalnih i postmenarhalnih devojčica iz Vršca. Glasnik ADJ.,48, pp. 57-64

Rao, S., Joshi, S. \& Kanade, A. (1998). Height velocity, body fat and menarcheal age of Indian girls. Indian Pediatrics, 35(7), pp. 619-628.

Salces, I., Rebato, M,E., Susanne, C., San Martin, L. \& Rosique, J. (2001). Familial resemblance for the age at menarche in Basque population. Annals of human Biology, 28(2), pp. 143-156.

Scepanovic, A. (2001). Populaciono-genetičke analize antropometrijskih i morfofizioloških karakteristika kod ispitanika različitog uzrasta stanovnika Pljevalja i Kotora. Magistarski rad. Univerzitet u Beogradu. Bioloski fakultet.

Scepanovic, A. (2013). Antropološke karakteristike djece sa dijagnozom asthma bronchiale. Doktorska disertacija, Univerzitet Crne Gore, Prirodno-matematički fakultet, Podgorica.

Sebek, G. (2013). Autochtonous cultivars of apple from the area of the upper Polimlje. Agriculture and Forestry, 59(3), pp.67-74.

Tatar, N. (2014). Fizičke aktivnosti u slobodnom vremenu mladih Crne Gore. Fakultet za sport i turizam, Novi Sad. 
Tesovic, Z., Balijagic, J., Petrovic, D., Jovancevic, M. (2012). Anthocyanins in indigenous and cultured fruit in Polimlje, North-east of Montenegro. Agriculture and forestry, 58(4), pp. 95-102.

Vujmilović, A. (2012). Relacije tjelesnih dimenzija i specifičnih motoričkih sposobnosti odbojkašica -kadetkinja u odnosu na igračku poziciju. Magistarski rad. Univerzitet u Banja Luci. Fakultet fizickog vaspitanja i sporta.

Wang, Y. \& Lobstein, T. (2006). Worldwide trends in childhood overweight and obesity. Int J Pediatr Obes, 1, pp. 11-25.

WHO. (2014). - Global Strategy on Diet, Physical Activity and Health. from

https://www.who.int/dietphysicalactivity/strategy/ 